\title{
Maternal transfer of organohalogenated compounds in sharks and stingrays
}

\author{
Liesbeth Weijs ${ }^{\mathrm{a}, \mathrm{b}, \mathrm{c}, *}$, Nathalie Briels ${ }^{\mathrm{a}, \mathrm{b}, \mathrm{d}}$, Douglas H. Adams ${ }^{\mathrm{e}}$, Gilles Lepoint ${ }^{\mathrm{f}}$, Krishna Das ${ }^{\mathrm{f}}$, Ronny Blust ${ }^{\mathrm{a}}$, \\ Adrian Covaci ${ }^{\mathrm{b}}$
}

a Department of Biology, University of Antwerp, Groenenborgerlaan 171, 2020 Antwerp, Belgium

${ }^{\mathrm{b}}$ Toxicological Centre, University of Antwerp, Universiteitsplein 1, 2610 Wilrijk, Belgium

' National Research Centre for Environmental Toxicology (Entox), The University of Queensland, 39 Kessels Road, Coopers Plains, QLD 4108, Australia

${ }^{\mathrm{d}}$ Norwegian University of Science and Technology (NTNU), Department of Biology, Høgskoleringen 5, Realfagbygget, 7491 Trondheim, Norway

${ }^{\mathrm{e}}$ Florida Fish \& Wildlife Conservation Commission, Fish \& Wildlife Research Institute, 1220 Prospect Ave., \#285, Melbourne, FL 32901, USA

${ }_{\mathrm{f}}^{\mathrm{f}}$ Laboratory for Oceanology - MARE Center, University of Liège B6C, 4000 Liège, Belgium

\section{A R T I C L E I N F O}

Article history:

Available online $\mathrm{xxxx}$

\section{Keywords:}

Bonnethead

Atlantic stingrays

Blacktip sharks

POPs

Maternal transfer

Embryo

\begin{abstract}
A B S T R A C T
Elasmobranchs can bioaccumulate considerable amounts of persistent organic pollutants (POPs) and utilize several reproductive strategies thereby influencing maternal transfer of contaminants. This study provides preliminary data on the POP transfer from pregnant females to offspring of three species (Atlantic stingrays, bonnethead, blacktip sharks) with different reproduction modes (aplacental, placental viviparity). Polychlorinated biphenyl (PCB) levels were generally higher than any other POPs. Stingrays and blacktip shark embryos contained the lowest POP concentrations while bonnetheads and the blacktip adult female had the highest concentrations. Results suggest that are more readily transferred from the mother to the embryo compared to what is transferred to ova in stingrays. Statistically significant differences in levels of selected POPs were found between embryos from the left and right uterus within the same litter as well as between female and male embryos within the same litter for bonnetheads, but not for the blacktip sharks.
\end{abstract}

(c) 2015 Elsevier Ltd. All rights reserved.

\section{Introduction}

Organohalogenated compounds can be passed between biota by several processes, including biomagnification, where pollutants in lower trophic level organisms are transferred to their higher trophic level predators. Biomagnification is a major pathway for several persistent organic pollutants (POPs) and is a frequent factor in biomonitoring studies (Kelly et al., 2004, 2008; Johnson-Restrepo et al., 2005; Burreau et al., 2006; Ikonomou and Addison, 2008). Additive to biomagnification, there is also the further potential of direct pollutant transfer from parent to offspring. This aspect of pollutant transfer has received comparatively less attention than biomagnification, although there have been a considerable number of studies regarding mammalian species (e.g. humans, marine mammals) dealing with body burdens of POPs in offspring (Soechitram et al., 2004; Greig et al., 2007; Vanden Berghe et al.,

* Corresponding author at: National Research Centre for Environmental Toxicology (Entox), The University of Queensland, 39 Kessels Road, Coopers Plains, QLD 4108, Australia. Tel.: +61 409581906.

E-mail addresses: liesbeth.weijs@uantwerpen.be, l.weijs@uq.edu.au (L. Weijs).
2012; Wang et al., 2012; Mori et al., 2014). Results for several contaminant classes have suggested a difference between prenatal maternal transfer (i.e. gestation) and postnatal maternal transfer (i.e. lactation) on the body burdens of POPs in mammalian offspring in terms of the types and amounts of contaminants (DeKoning and Karmaus, 2000; Ayotte et al., 2003; Guvenius et al., 2003).

Elasmobranch species have a wide variety of reproduction modes of which the influence on the maternal transfer during gestation remains largely unknown. Fortunately, recent attention has shifted to elucidating maternal transfer of POPs in several elasmobranchs. Lyons and Lowe (2013a,b) have investigated the mechanisms of maternal transfer of POPs in the common thresher shark (Alopias vulpinus), Lyons and Lowe (2013b) have focused on maternal offloading of POPs in round stingrays (Urobatis halleri), Mull et al. (2013) has found evidence of maternal offloading of POPs in young of the year white sharks (Carcharodon carcharias) and Olin et al. (2014) have attributed the high levels of PCBs (polybrominated biphenyls) found in juvenile bull sharks (Carcharhinus leucas) to maternal transfer. 
Reproduction modes in elasmobranchs range from oviparity to viviparity with wide variation in terms of presence of placenta and nourishment to the embryo (i.e. yolk sac, oophagy, embryonic cannibalism, uterine milk) (Gilmore, 1993; Bone and Moore, 2008). The elasmobranch species investigated in the current study were Atlantic stingrays (Dasyatis sabina), bonnetheads (Sphyrna tiburo) and blacktip sharks (Carcharhinus limbatus). The reproduction mode in Atlantic stingrays is aplacental viviparity with histotrophy during which the embryos are initially nourished by yolk sac (first stages of gestation) and then uterine milk (histotroph; later stages of gestation) before parturition (Bone and Moore, 2008). Bonnetheads and blacktip sharks are both placental viviparous species, where embryos derive nutrients from the yolk sac in the first stages of gestation after which the depleted yolk sac becomes highly vascularized providing nutrients to the embryos directly from the maternal bloodstream (Wourms, 1977; Bone and Moore, 2008).

Maternal transfer of POPs during gestation means that organisms are directly exposed to POPs, perhaps experiencing adverse effects, prior to birth. The influence of maternal transfer of POPs should be quantified and interpreted in species risk assessments. All species represented in this study have some similarities in terms of reproduction mode as they are all live bearers. However, there are important differences between the two reproduction modes in later stages of gestation as the stingray embryos rely on the protein and lipid-rich histotroph whereas blacktip sharks and bonnetheads rely on nutrients provided by the maternal bloodstream via pseudo placental connection. For lipophilic compounds, such as PCBs and PBDEs (polybrominated diphenyl ethers), the potential for maternal transfer can be greatly influenced by the type of tissue (Guvenius et al., 2003; Mori et al., 2014). Consequently, this may have a significant impact on the health and survival of embryos as a result of prenatal POP exposure as well as on the survival of newborns, juveniles and adults. Therefore, this study aims to provide further insight regarding the maternal transfer of selected POPs during gestation in three elasmobranch species that have two distinct reproduction modes.

\section{Materials and methods}

\subsection{Samples}

A total of 54 samples were analyzed for POPs and MeO-PBDEs (methoxylated polybrominated diphenyl ethers). These samples were from three different species (Atlantic stingray $-n=7$; bonnethead $-n=42$; blacktip shark $-n=5$ ) and included liver, ova, ovary or the combination ova \& ovary in case pre ovulated ova were too small to be analyzed separately (Table 1 ). In addition, dorsal muscle samples $(n=13)$ of one Atlantic stingray litter and one bonnethead litter were analyzed for stable isotopes $\left(\delta^{13} \mathrm{C}\right.$ and $\delta^{15} \mathrm{~N}$ ) to better understand their trophic position in relation to POPs. All sharks and rays were collected from estuarine waters of Indian River Lagoon (IRL) system on the Atlantic coast of Florida or from adjacent nearshore waters of the Atlantic Ocean from north of Cape Canaveral, Florida (latitude $28^{\circ} 40^{\prime} \mathrm{N}$ ) south to Sebastian Inlet, Florida (latitude $27^{\circ} 50^{\prime} \mathrm{N}$ ) during 2009 to 2012 . For the POP analysis, 38 PCB (polychlorinated biphenyls) congeners, six PBDEs (polybrominated diphenyl ethers), six DDXs (dichlorodiphenyltrichloroethane and isomers and metabolites), HCB (hexachlorobenzene), five chlordanes (CHLs) and four MeO-PBDEs were targeted in all samples.

\subsection{Sample preparation and POP analysis}

The method used for the sample extraction and cleanup has been previously described (Weijs et al., 2015) and is briefly presented below. Approximately $0.2-0.3 \mathrm{~g}$ of ova, $0.6-0.7 \mathrm{~g}$ of ovary, $0.3 \mathrm{~g}$ of embryo liver and $0.2 \mathrm{~g}$ of adult (mother) liver was homogenized with $\mathrm{Na}_{2} \mathrm{SO}_{4}$, spiked with internal standards BDE 77 and CB 143 and extracted by hot Soxhlet extraction for $2 \mathrm{~h}$ with hexane/acetone $(3 / 1 ; v / v)$. After lipid determination performed on an aliquot of the extract (typically $1 / 8$ th), the extract was cleaned on $8 \mathrm{~g}$ of acidified silica and analytes eluted with $20 \mathrm{ml}$ hexane and $15 \mathrm{ml}$ dichloromethane. The cleaned extract was evaporated to dryness and reconstituted in $150 \mu$ iso-octane. Details of the analytical methods are given in Weijs et al. (2009) and are briefly given here. PBDEs, MeO-PBDEs and CHLs were measured by GC$\mathrm{ECNI} / \mathrm{MS}$ (gas chromatography-electron capture negative ion/mass spectrometry) on a $30 \mathrm{~m} \times 0.25 \mathrm{~mm} \times 0.25 \mu \mathrm{m}$ DB-5 column by monitoring ions $m / z=79$ and 81 (for PBDEs and MeO-PBDEs) and 2 specific ions for each CHL. PCBs and DDXs were measured by GC-EI/MS (gas chromatography-electron ionization/mass spectrometry) on a $25 \mathrm{~m} \times 0.22 \mathrm{~mm} \times 0.25 \mu \mathrm{m}$ HT- 8 column by monitoring 2 ions for each homologue group. This system was also used to confirm MeO-PBDEs.

\subsection{Quality assurance/quality control (QA/QC)}

Recoveries for individual PCB and PBDE congeners ranged between $75 \%$ and $104 \%$ (RSD $<12 \%$ ). For each analyte, the mean procedural blank value was used for subtraction. After blank subtraction, the limit of quantification (LOQ) was set at 3 times the standard deviation of the procedural blank. For analytes that were not detected in procedural blanks, LOQs were calculated for a ratio $S / N$ equal to 10 . LOQs depended on the sample intake and on the analyte and ranged between 1 and $10 \mathrm{ng} / \mathrm{g}$ lipid weight (lw) (Table S1). QC was performed by regular analyses of procedural blanks, by random injection of standards and solvent blanks. A standard reference material SRM 1945 (PCBs, OCPs and PBDEs in whale blubber) was used to test the method accuracy. Obtained values did not deviate more than $10 \%$ from the certified values.

\subsection{Litters and statistical analysis}

Generally, levels of POPs were statistically tested and interpreted within each litter because the embryos were not in the same stage of development and because the mothers were not necessarily from the same age or area. Liver, ova and ovary samples of a pregnant female were also called a "litter" for consistency (Table 1). Results of embryos (per litter) were not pooled unless there were no statistically significant differences between female/male embryos or between embryos from the left or right uterus. Offspring/mother ratios were calculated and compared within the litter, within the species as well as among species. Overall, sample sizes were often too low to perform statistical analysis, but when possible, statistical tests were performed within each litter with non-parametric tests (Kruskal Wallis). For compounds that were detected in more than $50 \%$ of the samples, non-detects were replaced by a value of $f *$ LOQ ( $f$ is detection frequency and LOQ is limit of quantification). Statistical tests were performed using the SPSS software package (IBM SPSS Statistics Version 20). The level of statistical significance was $p=0.05$. All concentrations are expressed in ng per $\mathrm{g}$ lipid weight (lw).

\subsection{Stable isotopes}

Measurements of $\delta^{13} \mathrm{C}$ and $\delta^{15} \mathrm{~N}$ in muscle of one litter of Atlantic stingrays ( 1 mother and her 2 embryos) and one bonnethead litter ( 1 mother and her 9 embryos) were used to investigate the trophic position. Procedures for $\delta^{13} \mathrm{C}$ and $\delta^{15} \mathrm{~N}$ follow Weijs et al. (2015). Briefly, after freeze drying $(48 \mathrm{~h})$, muscle samples were ground into a homogeneous powder of which $1.5 \mathrm{mg}$ was used. 
Table 1

Lipid percentages of all samples analyzed in the present study.

\begin{tabular}{|c|c|c|c|c|c|}
\hline Species & & Tissue & Lipid percentage & Litter & Note \\
\hline Blacktip shark & $\begin{array}{l}\text { Mother } \\
\text { Embryo }\end{array}$ & Liver & $\begin{array}{l}31 \\
54 \\
48 \\
54 \\
57\end{array}$ & 4 & \\
\hline Atlantic stingray & $\begin{array}{l}\text { Mother } \\
\text { Embryo }\end{array}$ & Liver & $\begin{array}{l}49 \\
21 \\
45\end{array}$ & 1 & \\
\hline & $\begin{array}{l}\text { Mother } \\
\text { Mother }\end{array}$ & $\begin{array}{l}\text { Liver } \\
\text { Ova } \\
\text { Liver } \\
\text { Ova }\end{array}$ & $\begin{array}{l}8 \\
3 \\
52 \\
3\end{array}$ & $\begin{array}{l}2 \\
3\end{array}$ & \\
\hline Bonnethead & $\begin{array}{l}\text { Mother } \\
\text { Embryo }\end{array}$ & $\begin{array}{l}\text { Liver } \\
\text { Ova } \\
\text { Ovary } \\
\text { Liver }\end{array}$ & $\begin{array}{l}46 \\
17 \\
5 \\
20 \\
18 \\
19 \\
20 \\
19 \\
18 \\
19 \\
19 \\
20\end{array}$ & 5 & $\begin{array}{l}\text { Left uterus } \\
\text { Right uterus }\end{array}$ \\
\hline & $\begin{array}{l}\text { Mother } \\
\text { Embryo }\end{array}$ & Liver & $\begin{array}{l}55 \\
23 \\
20 \\
19 \\
22\end{array}$ & 7 & $\begin{array}{l}\text { Left uterus }^{\mathrm{a}} \\
\text { Right uterus }\end{array}$ \\
\hline & $\begin{array}{l}\text { Mother } \\
\text { Embryo }\end{array}$ & Liver & $\begin{array}{l}51 \\
21 \\
18 \\
20 \\
23 \\
17 \\
20 \\
10 \\
16 \\
20 \\
23\end{array}$ & 8 & $\begin{array}{l}\text { Left uterus } \\
\text { Right uterus }\end{array}$ \\
\hline & Mother & $\begin{array}{l}\text { Liver } \\
\text { Ova }\end{array}$ & $\begin{array}{l}40 \\
12\end{array}$ & 6 & \\
\hline & Embryo & Liver & $\begin{array}{l}20 \\
24 \\
23 \\
23 \\
22 \\
25\end{array}$ & & $\begin{array}{l}\text { Left uterus } \\
\text { Right uterus }\end{array}$ \\
\hline & Mother & $\begin{array}{l}\text { Liver } \\
\text { Ovary + ova }\end{array}$ & $\begin{array}{l}11 \\
3\end{array}$ & 9 & \\
\hline & $\begin{array}{l}\text { Mother } \\
\text { Embryo }\end{array}$ & $\begin{array}{l}\text { Ovary + ova } \\
\text { Liver }\end{array}$ & $\begin{array}{l}8 \\
21 \\
25 \\
24\end{array}$ & 10 & $\begin{array}{l}\text { Left uterus } \\
\text { Left uterus } \\
\text { Right uterus }\end{array}$ \\
\hline
\end{tabular}

\footnotetext{
a Pooled embryo livers from either the left or right uterus.
}

Samples were analyzed on a VG Optima (Micromass of IsoPrime100) IR-MS coupled to an N-C-S elemental analyzer (Carlo Erba) for automated analyses. Routine measurements are precise to $0.3 \%$ for both ${ }^{13} \mathrm{C}$ and ${ }^{15} \mathrm{~N}$. Stable isotope ratios were expressed in $\delta$ notation according to the following equation:

$\delta X=\left[\left(R_{\text {sample }}-R_{\text {standard }}\right) / R_{\text {standard }}\right] \times 1000$

where $X$ is ${ }^{13} \mathrm{C}$ or ${ }^{15} \mathrm{~N}$ and $R$ is the corresponding ratio $\left({ }^{13} \mathrm{C} /{ }^{12} \mathrm{C}\right.$ or $\left.{ }^{15} \mathrm{~N} /{ }^{14} \mathrm{~N}\right)$. Carbon and nitrogen ratios are expressed relative to the Vienna Pee Dee Belemnite (v-PDB) standard and to atmospheric nitrogen, respectively. Reference materials were IAEA $\mathrm{CH}-6$ (sucrose) $\left(\delta^{13} \mathrm{C}=-10.4 \pm 0.2 \%\right.$ ) and IAEA-N1 $\left(\delta^{15} \mathrm{~N}=+0.4 \pm 0.2 \%\right.$ ), respectively. Internal standards (glycin) were injected at regular intervals during all runs for calibration.

\section{Results}

\subsection{Lipid results and non-detects}

Lipid percentages in liver samples of blacktip sharks ranged from $31 \%$ for the mother to a mean ( \pm standard deviation; SD) lipid percentage of $53 \pm 4 \%$ for her embryos (Table 1 ). The lipid percentage in the stingray mother of litter 1 was $49 \%$ whereas lipid percentages in her two embryos were $21 \%$ and $45 \%$ (weight 60 and $67 \mathrm{~g}$, respectively, and disk width 128 and $127 \mathrm{~mm}$, respectively). The lipid percentage in the liver of the mother of litter 1 was intermediate between the lipid percentages of $8 \%$ and $52 \%$ in the livers of the mothers of litters 2 and 3, respectively. The lipid percentages in the ova were 3\% for both litters 2 and 3 (Table 1). For 
bonnetheads, there were no statistically significant differences per litter between the lipid percentages in the livers of embryos from the left uterus or right uterus (all $p>0.05$ ). Despite having comparable lipid percentages of the embryo livers within a specific litter or even across litters, the lipid percentages of the livers of the mothers covered a fairly broad range from $11 \%$ to $55 \%$. Ova and ovary tissue had lipid percentages lower than $20 \%$ (Table 1 ). PCB congeners 18, 44 and 87, 6-MeO-BDE 49 and 5-MeO-BDE $47+4-$ $\mathrm{MeO}-\mathrm{BDE} 49$ (co-elution) were not found in any sample investigated in the present study and are therefore not included in further calculations or discussions (Table S2).

\subsection{Levels and POP profiles}

\subsubsection{Dasyatis sabina - Atlantic stingray}

PCB 28, HCB and $o, p^{\prime}$-DDD were not found in any of the samples of Atlantic stingrays examined (Table S2). Another 14 PCB congeners (PCB congener numbers 52, 47, 49, 66, 74, 95, 110, 132, 151, $156,174,177,195,209), 5$ pesticides (o, $p^{\prime}$-DDE, o, $p^{\prime}$-DDT, $p, p^{\prime}-$ DDD, $p, p^{\prime}$-DDT, $p, p^{\prime}$-DDE), oxychlordane (OxC) as well as all PBDEs and MeO-PBDEs were only detected in less than $50 \%$ of the Atlantic stingray samples (Table S2). Overall, only higher chlorinated PCBs (20 congeners, starting from penta-PCB 99) and CHLs (trans-chlordane - TC, cis-chlordane - CC, trans-nonachlor - TN, cis-nonachlor - $\mathrm{CN}$ ) could be detected in more than $50 \%$ of the stingray samples. Across all three stingray litters, the sum of those 20 higher chlorinated PCBs was highest in one of the two embryos of litter 1 (1090 ng/g lw; Table S3) and lowest in a sample of a stingray ova of litter 3 (120 ng/g lw; Table S3). PCB levels were up to 4 times higher in embryos than in their mother (litter 1), whereas PCB levels were more than $50 \%$ lower in ova compared to their respective mother (litters 2 and 3) (Table S3). Similar as for PCBs, the highest $\sum$ CHL level was found in the embryo of litter 1 and the lowest level in the ova of litter 3. Also, $\sum$ CHL levels in ova of litters 2 and 3 were up to 4 times lower than $\sum$ CHL levels in their respective mothers. In contrast to this, $\sum \mathrm{CHL}$ in the mother was intermediate in between $\sum$ CHL levels in her two embryos instead of lower as for $\sum$ PCBs in this litter (Table S3).

The most dominant PCB was PCB 153 in all samples of all three stingray litters which contributed $22-35 \%$ to the sum of PCBs. This congener was followed by either PCB 187 (embryos of litter 1, ova and mother of litter 3), PCB 138 (mother of litter 1) or PCB 180 (ova and mother of litter 2). The most dominant compound among the CHLs was TN which contribution ranged from $26 \%$ to $49 \%$ of total CHLs. TN was followed by CC and CN in all samples. The PCB profiles given in Fig. 1A were comparable for ova-mother pairs (litters 2 and 3 ) whereas there was a slight difference in PCB proportions between the mother and her embryos (litter 1). Though the proportion of hexa-PCBs was similar, the mother (litter 1) had lower proportions of hepta- and octa-PCBs and higher proportions of penta-PCBs compared to her embryos (Fig. 1A).

\subsubsection{Carcharhinus limbatus - blacktip shark}

In all samples of blacktip sharks investigated in this study, 15 compounds were not detected at all and 5 compounds (BDE 28, 154, 153 and PCB 44, 174) were detected only in the liver of the mother (Table S2). In contrast to the Atlantic stingrays and bonnetheads, a higher number of compounds could be detected. Levels of $\sum$ PCBs (28 congeners) were consistently highest $(20,630 \mathrm{ng} / \mathrm{g} \mathrm{lw}$ for the mother, $1056 \pm 49$ (mean \pm SD) for the embryos) followed by $\sum$ DDXs $(1658 \mathrm{ng} / \mathrm{g}$ lw for the mother, $256 \pm 11$ (mean \pm SD) for the embryos) and $\sum$ CHLs (631 ng/g lw for the mother, $147 \pm 6$ (mean \pm SD) for the embryos) (Table S3). Concentrations of $\sum$ PBDEs were lowest in the mother $(190 \mathrm{ng} / \mathrm{g}$ lw for the mother, $19 \pm 4$ (mean $\pm \mathrm{SD}$ ) for the embryos), but not in the embryos where $\sum \mathrm{MeO}-\mathrm{PBDEs}$ were lowest (360 ng/g lw for the mother, $15 \pm 1$ (mean $\pm \mathrm{SD}$ ) for the embryos) (Table S3).

PCB 206 was predominant with $17 \%$ of $\sum$ PCBs in the mother followed by PCB 153 (15\% of $\sum$ PCBs). In contrast, PCB 153 was predominant among PCBs in the embryos followed by PCB 187 (on average $22 \%$ and $10 \%$ of $\sum$ PCBs for PCB 153 and PCB 187, respectively). $p, p^{\prime}$-DDE was predominant among DDXs in all samples ( $>90 \%$ of $\sum$ DDX in all blacktip sharks), TN had the highest contributions of CHLs ( $>45 \%$ of $\sum$ CHLs in all samples) and BDE 47 and 2-MeO-BDE 68 were the major compounds among PBDEs (50\% for the mother and $>70 \%$ for the embryos) and MeO-PBDEs ( $>55 \%$ for all samples), respectively. PCB profiles are given in Fig. 1B and show that the PCB profiles for the four embryos were very similar though they were different from the mother. The PCB profiles in the mother showed higher contributions of the higher chlorinated compounds (hepta to deca-PCBs) and minor contributions, if any, from the lower chlorinated compounds (tri to hexa-PCBs) (Fig. 1B).

\subsubsection{Sphyrna tiburo - bonnethead}

In all samples of bonnetheads investigated in the present study, 12 compounds were not detected in any sample and 16 compounds were detected only in $<50 \%$ of the samples (Table S2). Bonnetheads were in between the stingrays and the blacktip sharks regarding the number of compounds measured in $>50 \%$ of the samples (Table S2). Since there were no statistically significant differences in levels of sums of POPs and MeO-PBDEs between the embryos of left or right uterus within the same litter, all embryos could be pooled per litter. The highest levels of $\sum$ PCBs were found in the embryo livers of litter 7 (mean $\pm S D$, $11,632 \pm 536)$, of $p, p^{\prime}-\mathrm{DDE}, \sum \mathrm{CHLs}$ and $\sum$ PBDEs in the liver of the mother of litter $9\left(602,218\right.$ and $60 \mathrm{ng} / \mathrm{g}$ lw for $p, p^{\prime}$-DDE, $\sum$ CHLs and $\sum$ PBDEs, respectively) and of 6-MeO-BDE 47 in the liver of the mother of litter 8 (15 ng/g lw) (Table S3). PCB 206 is the most dominant PCB congener in all samples except for four samples where either PCB 153 or PCB 196/203 were the most dominant. There was no clear POP distribution pattern for these four samples and they could not be directly related to the patterns found in the other samples within the same litter. Among CHLs, TN (trans-nonachlor) had the highest levels, though there was one exception where oxychlordane had the highest levels. BDE 47 had the highest levels of PBDEs in all samples, accounting for $62-96 \%$ of the sum of PBDEs. PCB profiles are given in Fig. 1C. The profiles in liver of mother and embryos as well as in ova of litter 5 were similar whereas proportions of nona-PCBs were higher in the ovary compared to the liver samples of mother and embryos or ova. Similar profiles in livers of embryos compared to their mother were also found in litter 7. In litter 6, the PCB profiles in the liver of the embryos and in the ova were almost identical though both differed from the patterns seen in the liver of the mother. The liver of the mother in litter 8 had up to almost 2 times higher contributions of penta- and hexa-PCBs compared to her embryos. PCB profiles in the liver of the mother and in the ova and ovary were highly comparable in litter 9 . In contrast, there was a large difference, mostly in the proportion of nona-PCBs to the expense of octa-PCBs in the ovary and ova of litter 10 compared to the profiles of PCBs in the liver of the embryos. Overall, octa-PCBs were the most prevalent in most tissues except for the ovary + ova sample of litter 10 where nonaPCBs were prevalent (Fig. 1C).

\subsection{Offspring/mother ratios}

Levels of POP compounds in sharks and rays can be influenced by age, gender or location and habitats where they reside. In order to better interpret the maternal transfer of POPs and of 

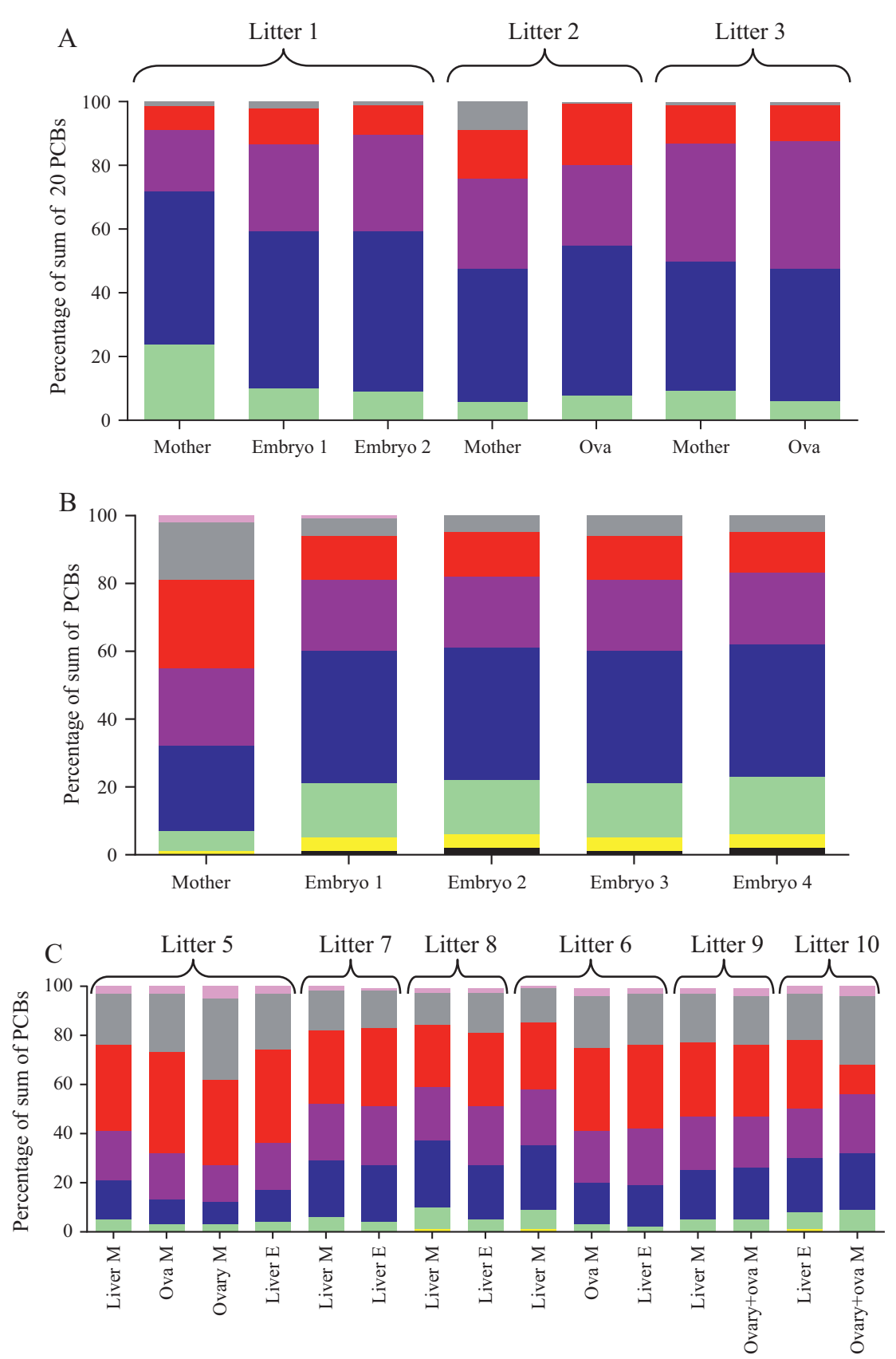

Fig. 1. Profiles of PCBs in tissues of (A) Atlantic stingrays, (B) blacktip sharks and (C) bonnetheads. $\boldsymbol{\square}=$ tri-PCBs, $=$ tetra-PCBs, $\square=$ penta-PCBs, $\square=$ hexa-PCBs, $\square=$ heptaPCBs, $\square=$ octa-PCBs, $\square=$ nona-PCBs, and $\square=$ deca-PCB.

MeO-PBDEs, levels in the offspring were standardized by calculating the offspring/mother ratios.

\subsubsection{Atlantic stingray}

Ova/mother ratios (litters 2 and 3; Table 2) were $\geqslant 1$ for $p, p^{\prime}$ DDE and BDE 47, but were lower than 1 for almost all other POPs. Embryo/mother ratios (litter 1 ; Table 2) were generally $\geqslant 1$ although there were differences between the female embryo/ mother ratios and the male/embryo mother ratios. Female embryo/mother ratios were $\geqslant 1$ for 25 out of 27 compounds whereas ratios of male embryo/mother were $\geqslant 1$ for 13 out of 27 compounds. For the male embryo/mother pair, ratios were $<1$ for the lower chlorinated PCBs, but $\geqslant 1$ for higher chlorinated PCBs. The highest ratios calculated for the embryo/mother pairs were for PCBs 180 and 170. This finding differed from the results in the ova/mother pairs where BDE 47 and $p, p^{\prime}$-DDE had the highest ratios.

\subsubsection{Blacktip shark}

Embryo/mother ratios were calculated for one near term litter of blacktip sharks. Embryos were pooled according to gender ( $n=2$ for female and male embryo groups). In contrast to the Atlantic stingrays, ratios were only $\geqslant 1$ for some of the lower chlorinated compounds ( 3 out of 45 compounds) and ratios for all compounds were comparable for the female embryo/mother and the male embryo/mother pairs. The highest ratios were found for PCB 28, which is the lowest chlorinated compound detected in the present study. Among PCBs, embryo/mother ratios decreased gradually with the degree of chlorination. Among DDXs, embryo/ mother ratios for $p, p^{\prime}$-DDD were highest followed by $p, p^{\prime}$-DDE 
Table 2

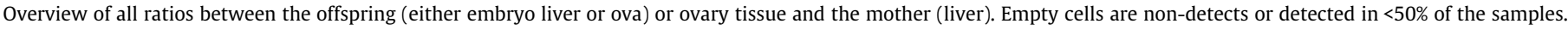
Bold numbers are ratios $\geqslant 1$.

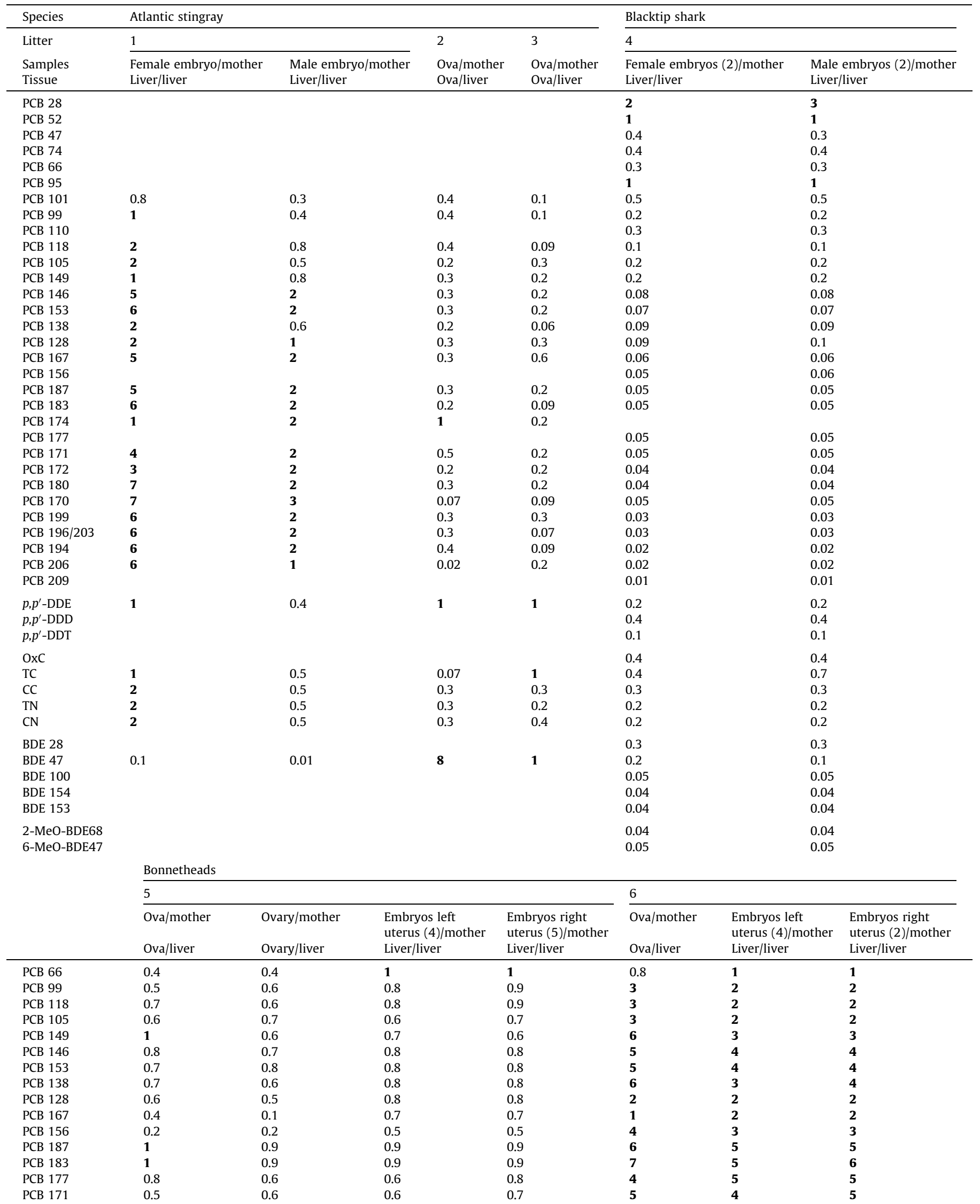




\begin{tabular}{|c|c|c|c|c|c|c|c|}
\hline РСВ 172 & 0.8 & 0.2 & 0.9 & 1 & 5 & 4 & 5 \\
\hline РСВ 180 & 0.9 & 1 & 0.8 & 0.9 & 9 & 7 & 8 \\
\hline РCВ 170 & 0.9 & 0.07 & 0.8 & 0.9 & 8 & 8 & 9 \\
\hline РСВ 199 & 1 & 1 & 1 & 1 & 9 & 6 & 7 \\
\hline PCB 196/203 & 1 & 1 & 1 & 1 & 11 & 7 & 8 \\
\hline РСВ 195 & 1 & 1 & 1 & 1 & 0.4 & 7 & 8 \\
\hline РСВ 194 & 1 & 0.01 & 1 & 1 & 10 & 7 & 8 \\
\hline РСВ 206 & 1 & 2 & 1 & 1 & 12 & 8 & 9 \\
\hline РСВ 209 & 1 & 2 & 1 & 1 & 12 & 7 & 8 \\
\hline$p, p^{\prime}-\mathrm{DDE}$ & 0.8 & 0.5 & 0.8 & 0.9 & 3 & 2 & 2 \\
\hline $\mathrm{OxC}$ & 0.7 & 0.5 & 1 & 0.9 & 2 & 2 & 3 \\
\hline $\mathrm{TC}$ & 0.5 & 0.5 & 0.7 & 0.8 & 1 & 1 & 1 \\
\hline $\mathrm{CC}$ & 0.5 & 1 & 1 & 1 & 6 & 3 & 2 \\
\hline $\mathrm{TN}$ & 0.7 & 0.5 & 0.8 & 0.8 & 2 & 1 & 2 \\
\hline $\mathrm{CN}$ & 0.6 & 0.6 & 0.9 & 0.8 & 2 & 1 & 1 \\
\hline BDE 47 & 0.6 & 0.5 & 0.8 & 0.8 & 4 & 2 & 2 \\
\hline BDE 100 & 0.4 & 1 & 0.4 & 0.5 & 4 & 2 & 3 \\
\hline BDE 154 & 1 & 0.8 & 1 & 0.9 & 2 & 1 & 1 \\
\hline \multirow[t]{4}{*}{ 6-MeO-BDE47 } & 0.2 & 0.2 & 0.3 & 0.2 & 0.5 & 3 & 3 \\
\hline & \multicolumn{7}{|l|}{ Bonnetheads } \\
\hline & \multicolumn{2}{|l|}{7} & \multicolumn{2}{|l|}{8} & 9 & 10 & \\
\hline & $\begin{array}{l}\text { Embryos left } \\
\text { uterus }(4) / \text { mother } \\
\text { Liver/liver }\end{array}$ & $\begin{array}{l}\text { Embryos right } \\
\text { uterus }(4) / \text { mother } \\
\text { Liver/liver }\end{array}$ & $\begin{array}{l}\text { Embryos right } \\
\text { uterus (5)/mother } \\
\text { Liver/liver }\end{array}$ & $\begin{array}{l}\text { Embryos left } \\
\text { uterus (5)/mother } \\
\text { Liver/liver }\end{array}$ & $\begin{array}{l}\text { Ovary + ova/ } \\
\text { mother } \\
\text { Ovary + ova/ } \\
\text { liver }\end{array}$ & $\begin{array}{l}\text { Embryos left } \\
\text { uterus/mother } \\
\text { Liver/ovary }\end{array}$ & $\begin{array}{l}\text { Embryos right } \\
\text { uterus/mother } \\
\text { Liver/ovary }\end{array}$ \\
\hline PCB 66 & 2 & 2 & 0.8 & 0.6 & 0.2 & 3 & 3 \\
\hline РСВ 99 & 2 & 2 & 1 & 0.9 & 0.3 & 3 & 3 \\
\hline РСВ 118 & 2 & 2 & 1 & 1 & 0.2 & 0.8 & 0.8 \\
\hline РCB 105 & 0.9 & 0.9 & 1 & 0.7 & 0.2 & 0.5 & 0.5 \\
\hline РСВ 149 & 2 & 2 & 1 & 0.8 & 0.3 & 1 & 1 \\
\hline РCB 146 & 3 & 3 & 2 & 1 & 0.3 & 0.9 & 0.9 \\
\hline РСВ 153 & 3 & 3 & 2 & 1 & 0.2 & 1 & 1 \\
\hline РСВ 138 & 3 & 3 & 2 & 1 & 0.2 & 0.8 & 0.8 \\
\hline РСВ 128 & 1 & 2 & 2 & 1 & 0.2 & 5 & 5 \\
\hline РСВ 167 & 1 & 2 & 2 & 1 & 0.1 & 3 & 4 \\
\hline РСВ 156 & 2 & 2 & 2 & 1 & 0.04 & 2 & 2 \\
\hline РСВ 187 & 3 & 3 & 2 & 2 & 0.2 & 1 & 0.9 \\
\hline РСВ 183 & 2 & 3 & 2 & 2 & 0.2 & 1 & 1 \\
\hline РСВ 177 & 3 & 3 & 3 & 2 & 0.2 & 1 & 1 \\
\hline РСВ 171 & 2 & 3 & 2 & 2 & 0.2 & 2 & 2 \\
\hline РСВ 172 & 3 & 3 & 2 & 2 & 0.1 & 3 & 2 \\
\hline РСВ 180 & 3 & 3 & 3 & 2 & 0.2 & 1 & 0.9 \\
\hline РСВ 170 & 0.9 & 3 & 3 & 3 & 0.2 & 8 & 8 \\
\hline РСВ 199 & 3 & 3 & 3 & 2 & 0.2 & 6 & 6 \\
\hline РCB 196/203 & 2 & 3 & 3 & 2 & 0.2 & 2 & 2 \\
\hline PCB 195 & 2 & 3 & 8 & 7 & 0.03 & 5 & 3 \\
\hline РСВ 194 & 3 & 3 & 3 & 2 & 0.2 & 31 & 29 \\
\hline РСВ 206 & 2 & 2 & 3 & 2 & 0.2 & 0.8 & 1 \\
\hline РСВ 209 & 2 & 2 & 3 & 2 & 0.3 & 0.7 & 0.7 \\
\hline$p, p^{\prime}-\mathrm{DDE}$ & 2 & 3 & 1 & 0.9 & 0.3 & 0.9 & 1 \\
\hline $\mathrm{OxC}$ & 1 & 1 & 1 & 0.8 & 0.4 & 5 & 4 \\
\hline TC & 2 & 1 & 0.8 & 0.6 & 0.7 & 4 & 1 \\
\hline $\mathrm{CC}$ & 1 & 0.9 & 0.6 & 0.5 & 1 & 5 & 0.5 \\
\hline $\mathrm{TN}$ & 2 & 2 & 1 & 0.8 & 0.3 & 3 & 1 \\
\hline $\mathrm{CN}$ & 2 & 2 & 1 & 0.8 & 0.2 & 1 & 2 \\
\hline BDE 47 & 2 & 2 & 1 & 0.9 & 0.2 & 0.3 & 0.6 \\
\hline BDE 100 & 3 & 2 & 2 & 2 & 0.2 & 1 & 1 \\
\hline BDE 154 & 2 & 2 & 3 & 2 & 0.2 & 1 & 1 \\
\hline 6-MeO-BDE47 & 0.2 & 0.4 & 0.3 & 0.3 & 1 & 2 & 1 \\
\hline
\end{tabular}

and $p, p^{\prime}$-DDT. Similar as for the PCBs, the embryo/mother ratios decreased with the degree of bromination for the PBDEs.

\subsubsection{Bonnethead}

Though there were no statistically significant differences in levels of sums of POPs in embryos from left or right uterus within the same mother (Table S4), there were differences for some individual compounds between embryos from the left or right uterus within the same mother. For that reason, offspring/mother ratios given in
Table 2 were calculated for offspring from the left uterus and offspring from the right uterus separately. For litter 6 , ova/mother ratios were highest for $\sum$ PCBs, followed by $\sum$ PBDEs, $p, p^{\prime}-\mathrm{DDE}$, $\sum$ CHLs and 6-MeO-BDE 47, respectively (Fig. 2A). For the same litter, embryo/mother ratios were highest for $\sum$ PCBs, followed by 6MeO-BDE 47, $\sum$ PBDEs, $p, p^{\prime}$-DDE and $\sum$ CHLs, respectively (Fig. 2B). For litter 5, ova/mother ratios were highest for $\sum$ PCBs, followed by $p, p^{\prime}$-DDE, $\sum$ PBDEs, $\sum$ CHLs and $6-\mathrm{MeO}-\mathrm{BDE} 47$, respectively whereas embryo/mother ratios were highest for $\sum$ PCBs followed 

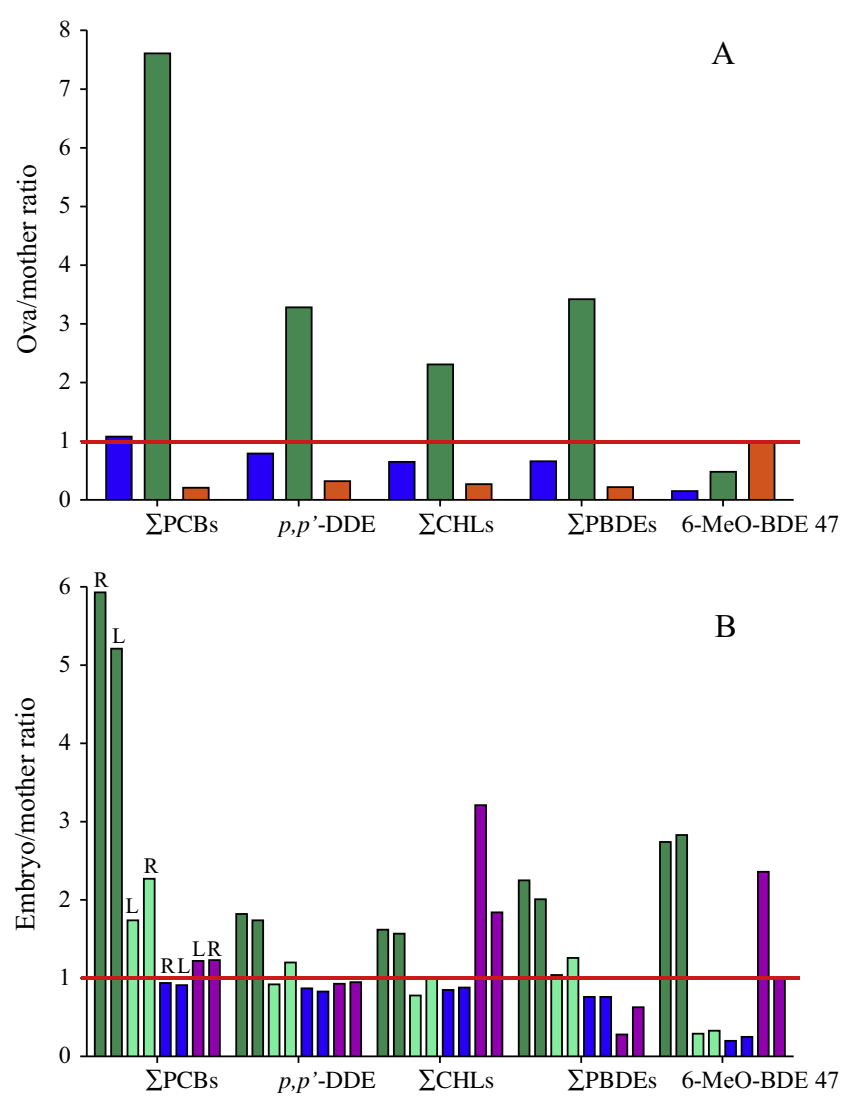

Fig. 2. Ova/mother ratios (A) and embryo/mother ratios vs stage of development (B) of bonnethead shark litters. Colors refer to the respective litter: = litter 9 (Note: ova + tissue of ovary was analyzed together), $\square=$ litter $6,=$ litter 8 , $\boldsymbol{\square}=$ litter $5, \boldsymbol{q}=$ litter 10 . Total body size $(\mathrm{TL})$ of the embryos was used as an estimation for stage of development with a mean minimum TL of $193 \mathrm{~mm}$ for the first column (litter 6) and a mean maximum of $275 \mathrm{~mm}$ for the last column (litter 10) of each compound class in graph B. R= right uterus, $L=$ left uterus. (For interpretation of the references to colour in this figure legend, the reader is referred to the web version of this article.)

by either $\sum$ CHLs or $p, p^{\prime}$-DDE, $\sum$ PBDEs and 6-MeO-BDE 47 (Fig. 2A and $\mathrm{B})$. With respect for each compound class, ova/mother ratios for litter 5 were lower compared to the embryo/mother ratios, except for $\sum$ PCBs. In contrast with litter 5 , ova/mother ratios from litter 6 were higher compared to the embryo/mother ratios for each respective compound class, except for 6-MeO-BDE 47 (Fig. 2A vs B). For litter 10, embryo/mother ratios of $\sum$ CHLs were highest and those of $\sum$ PBDEs were lowest. For litter 8 , embryo/ mother ratios of $\sum$ PCBs were highest and those for 6-MeO-BDE 47 were lowest. Overall, the offspring (both ova and embryos) from litter 6 accumulated the most and had levels almost up to 8 times the levels in the mother. The ova from litter 9 and the embryos from litter 5 accumulated the least from their respective mothers.

\subsection{Stable isotopes of pregnant females and embryos}

The bonnethead mother had higher values of $\delta^{13} \mathrm{C}$ and of $\delta^{15} \mathrm{~N}$ compared to her offspring, whereas the Atlantic stingray mother had intermediate values of $\delta^{13} \mathrm{C}$ and $\delta^{15} \mathrm{~N}$ compared to her two pups. Taking into account the concentrations of several POPs and MeO-PBDEs as measured in the liver of the same animals (Fig. 3), the bonnethead mother had lower levels of all POPs but not of 6MeO-BDE 47 compared to her offspring. This is in contrast with the Atlantic stingrays where the mother had intermediate $\delta^{13} \mathrm{C}$ and $\delta^{15} \mathrm{~N}$ values relative to her offspring, but higher levels of BDE
47 , intermediate levels of $\sum$ CHL and $p, p^{\prime}$-DDE and lower levels of $\sum \mathrm{PCB}$.

\section{Discussion}

The reproductive mode in Atlantic stingrays is aplacental viviparity, whereas bonnethead and blacktip sharks are placental viviparous. In both reproductive modes, embryos rely on the yolk in the initial stages of development. Further in their development, the embryos receive their nutrients from either the placenta (placental viviparity) or from enriched histotroph (aplacental viviparity).

\subsection{Atlantic stingrays}

Lyons and Lowe (2013b) have recently investigated the maternal offloading of DDT, chlordanes, and PCBs in round stingrays (Urobatis halleri) from the southern California coast. In that study, POP loads in the ova were lower than in the embryonic tissues and mothers were found to offload only low percentages of their total POP burdens to their offspring. In the present study, three litters of Atlantic stingrays were investigated of which two litters were composed of ova and their respective mother and one litter was composed of a female and male embryo with their mother. Offspring/mother ratios were calculated for all three litters. For the ova/mother pairs (litters 2 and 3; Table 2), ratios for $p, p^{\prime}$-DDE and BDE 47 were higher or equal to 1 indicating that these compounds are readily passed on from the mother to the ova. Except for TC, PCB 174, PCB 167 and PCB 171, ova/mother ratios for all other compounds were below the value of 0.5 . For the PCBs specifically, ova/mother ratios were comparable regardless of the degree of chlorination. Compared to the two ova/mother pairs (litters 2 and 3), the ratios of BDE 47 for the female and male embryo/ mother pairs (litter 1 , Table 2 ) dropped considerably from 8 (litter 2 ) and 1 (litter 3 ) to 0.1 and 0.01 . In serum of grey seals, there was a selective transfer of POPs, but transfer ratios of BDE 47 from maternal serum to milk were not particularly low compared to the ratios for HCB, DDXs, other PBDE congeners or tetra to nona-PCBs (Vanden Berghe et al., 2012). For the Atlantic stingrays however, partitioning of BDE 47 into the histotroph seems less efficient compared to all other compounds investigated. As such, the transfer of BDE 47 to the offspring may be reduced as the offspring has passed the initial stages of development where yolk reserves are the principle source of nutrients and subsequent pollutant transfer. Another possibility is that the embryos have well developed capacities for eliminating BDE 47. However, information about potential elimination pathways for PBDEs in stingrays is

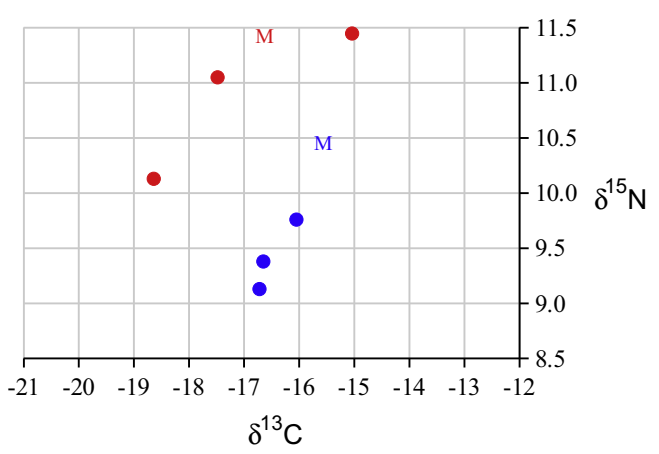

Fig. 3. Stable isotope signatures for muscle of Atlantic stingray and bonnethead mothers and offspring. $\mathrm{C}=\delta^{13} \mathrm{C}, \mathrm{N}=\delta^{15} \mathrm{~N}$, Atlantic stingray mother (M) with her 2 embryos, bonnethead shark mother $(\mathrm{M})$ with her 9 embryos (pooled into two groups according to their location which was either left or right uterus). 
non-existent. Atlantic stingray embryo/mother ratios increased with the degree of chlorination for the PCBs which is in contrast to the Atlantic stingray ova/mother ratios. This finding follows the findings of Debier et al. (2003) in grey seals. In Debier et al. (2003), higher chlorinated congeners were passed on more easily in late lactation than in early lactation due to a selective absorption of higher chlorinated PCBs by the pups.

\subsection{Blacktip sharks}

Ratios of blacktip shark embryo/mother pairs (litter 4; Table 2) were below 1 for all compounds investigated in the present study, except for PCBs 28, 52 and 95. Furthermore, focusing on PCBs only, ratios were decreasing with the degree of chlorination. These are remarkable results as they are exactly the opposite as what was found for the Atlantic stingray and most bonnethead embryo/ mother pairs suggesting that the POPs are not transferred via the placenta or that embryos are capable of not absorbing most POPs via placental transfer. Nevertheless, the levels in the blacktip shark embryos were still about $25 \%$ of the chemical load in their mother which is in contrast to the Atlantic stingray embryos who have much higher levels than their mother.

\subsection{Bonnetheads}

For the bonnethead sharks, offspring/mother ratios of litter 6 were generally all $>1$ except for the ova/mother ratio of $6-\mathrm{MeO}$ BDE 47 (Fig. 2). Compared to all other bonnethead shark litters, embryos of litter 6 were at the earliest stage of embryonic development. They resemble more the trends found in the Atlantic stingray embryo/mother pairs with higher embryo/mother ratios with degree of chlorination (for PCBs) which is the opposite of the trend found in the blacktip sharks. Offspring/mother ratios of litter 5 were generally all $<1$ except for the ova/mother ratio of $\sum$ PCBs (Fig. 2) and there was no increase in ratios for PCBs with degree of chlorination. For litters 5 and 6 , the trends seen in the ova/ mother ratios are maintained for the embryo/mother ratios. This trend was $\sum \mathrm{PCBs}>\sum \mathrm{PBDEs}>p, p^{\prime}-\mathrm{DDE}>\sum \mathrm{CHL}$ for litter 6 and $\sum \mathrm{PCBs}>p, p^{\prime}$-DDE $>\sum \mathrm{CHLs}>\sum \mathrm{PBDEs}$ for litter 5 . Ratios between ovary tissue with ova and the liver of the mother of litter 9 were all $<1$ except for 6-MeO-BDE 47. It is unclear why there were differences in ratios between the embryos of the left and right uterus for litters 8 and 10. The highest offspring/mother ratio in this study was calculated for the embryos from litter 10 and these ratios were 31 and 29 for PCB 194 for the embryos of the left and right uterus, respectively. This indicates that PCB 194 can readily be passed on to the offspring, however that does not apply to all litters examined.

\subsection{Stable isotopes in pregnant females and embryos}

For the stingray litter, the mother was found to be intermediate in between her two embryos when it comes to $\delta^{13} \mathrm{C}$ and $\delta^{15} \mathrm{~N}$ values. For the bonnethead litter, the mother was found to have higher $\delta^{13} \mathrm{C}$ and $\delta^{15} \mathrm{~N}$ values than her near-term embryos. In the literature, embryos have been found to have higher $\delta^{13} \mathrm{C}$ and $\delta^{15} \mathrm{~N}$ values compared to their mother in Atlantic sharpnose sharks (Rhizoprionodon terraenovae; McMeans et al., 2009) and decreasing $\delta^{13} \mathrm{C}$ and $\delta^{15} \mathrm{~N}$ values have been found in neonatal bull sharks and Atlantic sharpnose sharks (Olin et al., 2011). However, these results do not apply for the stingray litter and bonnethead litter for which muscle tissues were available for stable isotope analyses.

\subsection{Conclusions}

The embryos investigated in the present study were almost all in different stages of development, which likely added variability to our results. In addition, the pregnant females examined were not necessarily from the same area and can be migratory. Calculating offspring/mother ratios is a way to standardize the levels of compounds, but cannot erase the pollutant profiles and signatures in the mother, which are reflective of diet and spatial variation. Since the minimum and maximum concentrations for PCBs, PBDEs, DDXs, MeO-PBDEs and CHLs covered a broad range of concentrations and profiles in the mothers investigated in this study, there is consequently also a lot of variation in offspring/mother ratios which makes it difficult to draw firm conclusions about the maternal transfer of POPs and of MeO-PBDEs in these species, however, the present study provides preliminary results for aspects which deserve to be investigated more thoroughly in future studies.

\section{Acknowledgements}

A.C. and L.W. are grateful to the University of Antwerp (UA) for financial support. K.D. and G.L. are F.R.S.-FNRS Research Associates. Sharks and stingrays for this study were collected by the Florida Fish and Wildlife Conservation Commission - Fish and Wildlife Research Institute's Fisheries-Independent Monitoring Program. Many thanks to Eric Reyier of Kennedy Space Center's Ecological Program for providing additional bonnethead sharks for this study.

\section{Appendix A. Supplementary material}

Supplementary data associated with this article can be found, in the online version, at http://dx.doi.org/10.1016/j.marpolbul.2014. 12.056 .

\section{References}

Ayotte, P., Muckle, G., Jacobson, J.L., Jacobson, S.W., Dewailly, E., 2003. Assessment of pre-and postnatal exposure to polychlorinated biphenyls: lessons from the Inuit Cohort Study. Environ. Health Perspect. 111, 1253-1258.

Bone, Q., Moore, R., 2008. In: Owen, E. (Ed.), Biology of Fishes, third ed. Taylor \& Francis Group, Abingdon, UK.

Burreau, S., Zebühr, Y., Broman, D., Ishaq, R., 2006. Biomagnification of PBDEs and PCBs in food webs from the Baltic Sea and the northern Atlantic Ocean. Sci. Total Environ. 366, 659-672.

Debier, C., Pomeroy, P.P., Dupont, C., Joiris, C., Comblin, V., Le Boulengé, É., Larondelle, Y., Thome, J.P., 2003. Dynamics of PCB transfer from mother to pup during lactation in UK grey seals Halichoerus grypus: differences in PCB profile between compartments of transfer and changes during the lactation period. Mar. Ecol.-Prog. Ser. 247, 249-256.

DeKoning, E.P., Karmaus, W., 2000. PCB exposure in utero and via breast milk. A review. J. Expo. Anal. Environ. Epidemiol. 10, 285-293.

Gilmore, R.G., 1993. Reproductive biology of lamnoid sharks. Environ. Biol. Fishes 38, 95-114.

Greig, D.J., Ylitalo, G.M., Hall, A.J., Fauquier, D.A., Gulland, F.M.D., 2007. Transplacental transfer of organochlorines in California sea lions (Zalophus californianus). Environ. Toxicol. Chem. 26, 37-44.

Guvenius, D.M., Aronsson, A., Ekman-Ordeberg, G., Bergman, Å., Norén, K., 2003. Human prenatal and postnatal exposure to polybrominated diphenyl ethers, polychlorinated biphenyls, polychlorobiphenylols, and pentachlorophenol. Environ. Health Perspect. 111, 1235-1241.

Ikonomou, M.G., Addison, R.F., 2008. Polybrominated diphenyl ethers (PBDEs) in seal populations from eastern and western Canada: an assessment of the processes and factors controlling PBDE distribution in seals. Mar. Environ. Res. 66, 225-230.

Johnson-Restrepo, B., Kannan, K., Addink, R., Adams, D.H., 2005. Polybrominated diphenyl ethers and polychlorinated biphenyls in a marine foodweb of coastal Florida. Environ. Sci. Technol. 39, 8243-8250.

Kelly, B.C., Gobas, F.A.P.C., McLachlan, M.S., 2004. Intestinal absorption and biomagnification of organic contaminants in fish, wildlife, and humans. Environ. Toxicol. Chem. 23, 2324-2336.

Kelly, B.C., Ikonomou, M.G., Blair, J.D., Gobas, F.A.P.C., 2008. Bioaccumulation behaviour of polybrominated diphenyl ethers (PBDEs) in a Canadian Arctic marine food web. Sci. Total Environ. 401, 60-72. 
Lyons, K., Lowe, C.G., 2013a. Mechanisms of maternal transfer of organochlorine contaminants and mercury in the common thresher shark (Alopias vulpinus). Can. J. Fish. Aquat. Sci. 70, 1667-1672.

Lyons, K., Lowe, C.G., 2013b. Quantification of maternal offloading of organic contaminants in elasmobranchs using the histotrophic round stingray (Urobatis halleri) as a model. Environ. Sci. Technol. 47, 12450-12458.

McMeans, B.C., Olin, J.A., Benz, G.W., 2009. Stable-isotope comparisons between embryos and mothers of a placentatrophic shark species. J. Fish Biol. 75, 24642474.

Mori, C., Nakamura, N., Todaka, E., Fujisaki, T., Matsuno, Y., Nakaoka, H., Hanazato, M., 2014. Correlation between human maternal-fetal placental transfer and molecular weight of PCB and dioxin congeners/isomers. Chemosphere 114, 262-267.

Mull, C.G., Lyons, K., Blasius, M.E., Winkler, C., O’Sullivan, J.B., Lowe, C.G., 2013. Evidence of maternal offloading of organic contaminants in white sharks (Carcharodon carcharias). PLoS One 8, e62886.

Olin, J.A., Hussey, N.E., Fritts, M., Heupel, M.R., Simpfendorfer, C.A., Poulakis, G.R., Fisk, A.T., 2011. Maternal meddling in neonatal sharks: implications for interpreting stable isotopes in young animals. Rapid Commun. Mass Spectrom. 25, 1008-1016.

Olin, J.A., Beaudry, M., Fisk, A.T., Paterson, G., 2014. Age-related polychlorinated biphenyl dynamics in immature bull sharks (Carcharhinus leucas). Environ. Toxicol. Chem. 33, 35-43.
Soechitram, S.D., Athanasiadou, M., Hovander, L., Bergman, Å., Sauer, P.J.J., 2004 Fetal exposure to PCBs and their hydroxylated metabolites in a Dutch cohort. Environ. Health Perspect. 112, 1208-1212.

Vanden Berghe, M., Weijs, L., Habran, S., Das, K., Bugli, C., Rees, J.F., Pomeroy, P., Covaci, A., Debier, C., 2012. Selective transfer of persistent organic pollutants and their metabolites in grey seals during lactation. Environ. Int. 46, 6-15.

Wang, D., Atkinson, S., Hoover-Miller, A., Shelver, W.L., Li, Q.X., 2012. Organic halogenated contaminants in mother-fetus pairs of harbor seals (Phoca vitulina richardii) from Alaska, 2000-2002. J. Hazard. Mater. 223-224, 72-78.

Weijs, L., Dirtu, A.C., Das, K., Gheorghe, A., Reijnders, P.J.H., Neels, H., Blust, R., Covaci, A., 2009. Inter-species differences for polychlorinated biphenyls and polybrominated diphenyl ethers in marine top predators from the southern North Sea: Part 1. Accumulation patterns in harbour seals and harbour porpoises. Environ. Pollut. 157, 437-444.

Weijs, L., Briels, N., Adams, D.H., Lepoint, G., Das, K., Blust, R., Covaci, A., 2015. Bioaccumulation of organohalogenated compounds in sharks and rays from the southeastern USA. Environ. Res. 137, 199-207.

Wourms, J.P., 1977. Reproduction and development in chondrichthyan fishes. Am. Zool. 17, 379-410. 